\title{
Need for Increasing Grammar Focus in English Teaching: A Case in Indonesia
}

\section{Bambang Sugeng}

English Education Department, Faculty of Languages and Arts, Yogyakarta State University; ba_geng@yahoo.com

\author{
Doi:10.5901/jesr.2015.v5n3p131
}

\begin{abstract}
The study was aimed at finding out the level of students' grammatical quality in their use of English in conversations. The subjects were 301 year-2, year-3, and year-4 undergraduate students of the English Study Programs of 36 state and private teacher training universities from 16 of the 34 provinces in Indonesia. The study was descriptive qualitative of the observationtype research method for the data-collection technique using an open-ended observation guide as the research instrument. Data were sorted into categories, counted, and ranked by frequencies of occurrences. Research results showed that, regardless of their years, students had a low level of grammatical quality in their language use. In a rank, their grammatical problems were related to verb group, finite verbs, subject-verb concords, predicates, concords of nouns, word choices, and others. Suggestions were proposed that the teaching of English as a foreign language should bring back grammar into its appropriate place. Compared to first and second language teaching, a rough ratio of 20 by 80 percent between fluency and accuracy would be acceptable.
\end{abstract}

Keywords: grammar focus, fluency, accuracy, grammar teaching, TEFL in Indonesia

\section{Introduction}

The teaching of English as a foreign language in Indonesia (TEFLIN) has undergone several curricular changes. The first known curriculum was the grammar-translation curriculum that was in use up to around the second half of the $20^{\text {th }}$ century. In the class interaction, the teacher would come into class with a pocket-size book, looking rather old and shabby, opened it on the due page, asked one student (usually the same person) to write the selected material on the black chalkboard; a reading passage and its 5 to 10 essay-type comprehension questions, the rest of the class copying it in their writing books. One by one, the students read one sentence and translated it into Indonesian, the teacher helping with the vocabulary. The lesson was ended by the teacher giving homework to memorize assigned vocabulary words.

The second curriculum was the behavioural, direct, aural-oral type practiced between around the 1950s and the 1970s. In this curriculum type, the teacher would enter the classroom and started the class with the well-practiced greeting, asked the students to open the Student Book on the due page, and led the class to do the listen-and-repeat activities of language drills. She would pronounce a word, phrase, or sentence and the students would repeat after her. She would not stop and go to the next word, phrase, or sentence till she looked satisfied with the class repetition. She would vary the turn giving; individually, by small groups, by class halves, and by the whole class.

The third curriculum type was known as the eclectic method, vaguely (or even wrongly) understood as the "mixture" between the traditional grammar-translation method and the direct, aural-oral approach. There was an understanding, however, that the former was an old method, the latter was new, and the former should be replaced by the latter. Teachers were quite comfortable with the eclectic teaching mode as weaknesses and difficulties in the two methodologies could complement each other. Besides, the teachers were able to practice a certain amount of freedom in their classroom techniques. This curriculum was implemented nationally in the 1970s and was well-accepted by those who were in the educational field.

The fourth curriculum was the communicative type which came in 1984 and which was officially stipulated by a governmental decree, via the Ministry of Education and Culture, as the national approach to TEFLIN. The decree was greeted with enthusiasm among teachers as it promised the outcome that, at the end of instruction, students would be able to communicate effectively. Syllabuses came and went in line with the changes in the national curricula applying the competency-based education (1980s), school-based curriculum (1990s), and character-based education (2000s). Syllabuses also changed in orientations giving emphases on learning objectives, learners' competencies, instructional contents, classroom techniques, text types, and genre. The communicative methodology remained the teaching mode in the English classes.

The changes in the curricula of TEFLIN have, up to the present time, shown much inadequacy in the students' 
quality of their English usage. Nation-wide, students of English departments speak English fluently but with a grammar quality that is unbelievably inferior. It seems clear that students do not possess consciousness of grammar usage and that they do not consider that speaking or writing with correct grammar is important. Many staff members are amazed at the multitude of the mistakes in each paper and the simplicity of the mistakes that the students make. Frequentlyoccurring mistakes are like the ones found in these two paragraphs below.

The child whom the researcher is deals is fandi bramantya/bram. he is 22 months. he is my son, we live together and I can observe and explore every word's utterances. Now he can produces several words clearly but sometime his words understandable to express his want, my son sometime use gesture. He can produces one word, there are 7 words (ex, emoh ..., adya, mama, papa, baba) and produces two word (like, ojo to ...). He can produces babbling with vowel syllabel like $a, i, u, e, o$ and ...

Many learners couldn't learn effectively, Many problems which are happened in English learning, especially in creativity case, in which, the way of learning can bored the learners. When the learners asked to finish the assignment, it will probably the learners cheat classmates' answer or they will copy paste answer by internet explorer. It is always challenge to get in touch talking, discussing and sharing about the problem of teaching and learning process. Some argues that teaching English in Indonesia failed because of most students do not able to show their communicative competence.

Errors such as in the examples above are common place and students do not seem to be concerned with such mistakes. The negligence of grammatical accuracy in the language class tends to lower students' awareness of the need to speak the language well with correct grammar. In addition to this, under the pressure of the misapplication of the communicative methodology, teachers tend to show the impression to the students that grammatical accuracy is not important.

Low accuracy in language use becomes doubled in speech. Students are so fluent in formal speech but with an accuracy of almost zero. There are mistakes in the grammatical structures, pronunciation, and word choices. In classroom interactions, seminar discussions, and other formal discourse venues, almost all students speak fluently to the extent of using the glottal stops (most commonly: [ðæ?] for 'that', [b^?] for 'but', [n०?] for 'not', and some others) and slang expressions (most commonly: [ai won ə] for 'I want to', [wi ə gon ə] for 'We are going to', and some others) in the environment of grammatically incorrect sentences and distinctively non-standard pronunciation in their speech.

In pronunciation, students from different ethnic backgrounds have different peculiarities due to the characteristics of their ethnic tongues. However, many of the errors can be traced to insufficient instructional practice in the classroom. Common inaccuracy in the students' pronunciation occurs in certain sounds and syllable stresses such as those in 'target', 'event', 'although', 'high', 'sentence', 'language', 'purpose', and 'interesting'.

There was a time in an almost forgotten past when English teaching was highly structured and class proceedings were characterized by controlled practices in the use of language constructions. The learning of English grammar became the focus of the English syllabus. Instructional controls took forms in various intensities starting from the strictest to the least. In the former, students were given sentence drills during which the same sentences were repeated again and again by changing one of the words in the sentences. In the later, drilling was presented in a contextual, situational manner so that repetition was obscured among the more communicative activities. What was important was that students' produced sentences were grammatically correct although fluency and authenticity were negated by the mechanical natures of the teaching techniques.

But these mechanical techniques of teaching did touch the basics. Through the pattern drills, the English teacher was able to plant in the students' language repertoire grammar rules acquired unconsciously from the repeated practice of the sentences. The immediate product of this instructional activity was that students were able to say sentences, hopefully automatically, in the classroom. But, a follow-up of this immediate learning was that students would be able to develop, in a future, this mechanical competency into more communicative language abilities facilitated by various demands and supports in their real-life situations. As suggested by Hammerly (1991: 46), a systematic language basis is not only possible but essential in learning a language provided that what is learned linguistically is also used communicatively.

An acute obsessive concern is, thus, how the learning of English as a foreign language in Indonesia produces users who possess the expected English proficiency with both fluency and accuracy. The expectation may be unrealistic when it is related to use of English for general purposes. However, when it comes to the requirement for which school teachers become models for their students, it is a real, urgent one. We want Indonesian speakers of English as a foreign language to be able to use the English language well. 


\section{Grammar Focus in the Syllabus}

The grammar of a language is the symbolic, conventionalized rule of language use which shows relationships between forms and meaning (Trousdale and Gisborne, 2008: 2) and distinguishes between correct and incorrect expressions (Young, 1984:11). A grammar attempts to describe the system of communication which every normal member of the community of the language 'possesses' and which is shared by the community at large. A grammar of a language is given. It exists together with the language itself. It defines what counts as the language. The grammar of English shows that English is exactly as Indonesian, or any other language in this matter, is.

The grammar of a language carries at least four characteristics. First, grammar is prescriptive. It tells the user of the language how to use the language in a decent way. It is like rules of etiquette which become the starting point for people to interact. In any language use, one can always distinguish between "decent use" and "poor use" of the language. Second, grammar is meaningful. For one thing, the elements of grammar-like vocabulary items-have meanings in their own right. They are like idiomatic expressions that are formed by the speakers of the language arbitrarily. The past tense, for an example of a grammatical item, carries the meaning that the event represented by the verb happens in the past. Third, the grammar of a language carries a number of functions. One function is called the ideational or representative function in which one uses a language to express one's interpretation of the world. Other functions are those of intra-personal, interpersonal, linguistic, meta-linguistic, textual, and others. Fourth, grammar is grounded in physical reality through the rules of grammar, syntactic tree diagrams, grammatical formulas, syntactic patterns, mnemonics, and others. These physical representations of grammar are especially, and traditionally, useful in language education in the language classroom.

Different syllabi give different status and emphases in the classroom learning and teaching processes. In the traditional grammar-translation syllabus, grammar becomes the main focus of the classroom instruction. The instructional process revolves around grammatical points. In the aural-oral syllabus, grammar is not taught, relying on the assumptions that learners will internalize grammatical rules as the direct-mode instruction proceeds. Explicit grammar explanation may be given in the advanced phase of the syllabus. In the communicative-based syllabi, grammar is placed in a later section of the instructional scheme, as a supporting material to/for the main focus of the syllabus. Grammatical explanation and practice are presented in communicative tasks and activities such as communication gaps and songs and games for explicit grammar exercises.

A huge amount of research (e.g. Purpura, 2004; Swan, 2006; Thornbury, 2002; Zhang. 2009) gives a clear hint that grammar instruction in language classes is useful for helping the learners to develop their communicative competences, albeit the never-ending dissenting opinions about it. This is hardly surprising since old-fashioned language educators would want to maintain that grammar cannot be separated from language teaching. A neglect of grammar will eventually give impeding effects on the language learners when coming to language use in the real environment. The teaching of grammar is an inherent part of the teaching of language taking careful precautions that it must not interfere with the learners' motivation and convenience in the day-to-day classroom activities.

At the present time, the teaching of grammar has been reduced to almost zero in the language classes. Grammar has been associated with such negative reputations that it has a bad name, is associated with a trivial insistence on niceties, is often presented through mechanical exercises, and deals with such fruitless learning as irregularities of forms and the memorization of seemingly endless paradigms of constructions (Langacker, 2008: 4; Young, 1984: 11). This is often worsened by class teachers' attitudes that teaching grammar is "sinful", useless, and against the doctrines of modern language teaching methodologies. Grammar teaching is simply wrong and must be avoided.

Looking at the status and function of grammar in language use, it does not have to be like that. A change in language teaching methodology that puts aside the teaching of grammar is a change that is radical (Brown 2000: 267). Properly speaking, grammar must still be an important part of a language class. Whether a curriculum or textbook is billed as functional, communicative, structural, or whatever, grammar and grammar sequencing is an issue (Brown 2000: 118). In a rather extreme manner, Jackson (2005: 4) states that grammar is an essential component of both spoken and written language and that language would not be language without grammar.

The placement of grammar focus in the communicative syllabuses does not violate the theory and principles of communicative teaching in so far as it does not interfere with fluency development (Richards, 2009, e.g. p. 26; Zhang. 2009 185;). Some sort of formal instruction is required for raising the learners' consciousness of grammatical structures in the target language. In order to promote an advanced level of a target language attainment (Jackson, 2005; 98), there seems to be a growing consensus that grammar must play a larger role in the classroom than that granted by the communicative approaches of the 1980s (Campoy-Cubillo, Belles-Fortuno, and Gea-Valor, 2010 183-4.). Use of correct English is one that effectively and aesthetically is pleasing to the listener or reader (Jespersen, 2006: 17-8). Grammar 
can be taught in class by integrating it into extensive reading and writing, presenting it in communicative grammar exercises (such as what is done in the syllabuses of Indonesian university English departments), or drilling it in the language-focus of classroom English (e.g. Swan, 2006; Thornbury, 2002). Finally, Brumfit (1981) maintains that a focus on grammar need not divert the learners' attention away from the meaning of what they are exposed to, provided, of course, that the teacher succeeds in embedding the particular pattern(s) to be focused upon into a communicative framework in a natural way.

\section{The Research Study}

The study was descriptive qualitative using an observation-type research method for the data-collection technique. The aim of the study was to find out the level of the grammatical quality used by students of teacher-education institutions. Assignments of levels were based on the magnitudes of grammatical errors that students made during conversation events. A high level showed a few mistakes, a medium level showed a middle position, and a low level showed a great number of errors.

The subjects were 301 undergraduate students of the English Study Programs of teacher training universities. They came from 16 of the 34 provinces in the six big islands of Sumatera, Java, Kalimantan, Sulawesi, Nusa Tenggara, Maluku and Papua amounting to 36 state and private teacher training universities. The distribution of the subjects was: 86 Year-2 students, 140 Year-3 students, and 75 Year-4 students. In the Indonesian education system, they were of the S-1 program designated to teach in primary and high schools after graduation.

Data were in the forms of students' spoken sentences elicited through group-discussion activities. The observation guide was an open-ended question list consisting of: personal identity, why they study in or like their school, what they think of the teachers and facilities of their school, their intra- and extra-curricular activities, and their opinions or suggestions to make their school a better place to study. In each school, the conversation group consisted of 2 to 3 year2 students, 4 to 6 year-3 students, and 2 to 3 year-4 students. Careful group management was applied to ensure that participants felt comfortable and spoke freely without any pressure.

Data analysis procedure consisted of grouping, counting, and ranking. In the grouping step, wrong phrases or sentences were sorted into types of mistakes. In the counting step, the phrases and sentences in each type were manually counted by numbers. In the ranking step, the mistake types were ranked by frequencies of occurrence. The data analysis produced a ranking seven types of mistakes.

Findings showed that, regardless of their years, students had a low level of grammatical quality in their language use. Mistakes occurred in almost every sentence they made and observation tended to indicate that they were not conscious of their mistakes. The low level of grammatical accuracy was doubled by poor pronunciation and inappropriate uses of slang expressions. Below is a list of the grammatical mistakes made by the research participants ranked in seven types based on their frequency of occurrence:

\begin{tabular}{|c|c|}
\hline \multirow[t]{3}{*}{ - Verb groups } & - is deals \\
\hline & - can produces \\
\hline & - He would gave punishment. \\
\hline - Finite verbs & $\begin{array}{l}\text { - Even she known student understanding or not. } \\
\text {-We already done to do English Examination. } \\
\text {-... english becoming a subject that compulsory in Indonesia. }\end{array}$ \\
\hline - Subject-verb concords & $\begin{array}{l}\text { - He seldom teach and gave homework. } \\
\text {-... the way teacher deliver lesson in teaching learning process. } \\
\text { - The student who understand or not is same score. }\end{array}$ \\
\hline - Predicates & $\begin{array}{l}\text {-...students interested in learning, } \\
\text {-... my classmate confused why they had to did that because ... } \\
\text { - We very disappointed. }\end{array}$ \\
\hline - Concords of nouns & $\begin{array}{l}\cdot . . . \text { as many as score ... } \\
\text {-... one of my teacher who ... } \\
\text { - He gave us exercises as much as possible. }\end{array}$ \\
\hline - Word choices & $\begin{array}{l}\text { - It made the student be enthusiasm } \\
\text { - She always gave directly feedback ... } \\
\text { - In give evaluation, he just gave ... }\end{array}$ \\
\hline - Others & $\begin{array}{l}\text { - When the learners asked to finish ... } \\
\text { - I was lack of vocabulary } \\
\text { - Although I never got it but this method.. }\end{array}$ \\
\hline
\end{tabular}


The situation now is ugly, closing to frightening. High-school graduates and university students have imbalanced measure of fluency and accuracy in their English proficiency as a result of their English education. They can speak or write English in notable fluency but with a markedly low level of accuracy. This can be traced to the insufficient provision of grammar focus in the school syllabus. A change is urgently needed in the syllabus to provide a more balanced treatment of fluency and accuracy by giving a larger amount of grammar teaching in the classroom. A share estimate of 50-50 between fluency and accuracy gives the students possibility to be able to speak or write English fluently with good grammar. Language focus can be oriented at grammatical items that are specific for Indonesian learners such as finite verbs and concords and pronunciation practice on a number of particular sounds and syllable stresses.

\section{Discussion}

Grammar teaching needs to be put back in the syllabus. An urgent need is felt to return to the proper understanding of the teaching of grammar in the language class to be both experiential and referential. In the former case, all English language learning syllabi include grammar as an important part of instruction. In any classroom syllabus, an ultimate question will be how well the learners use the language in terms of grammatical correctness. In the latter case, the classroom involves conscious, explicit grammar instruction. Teachers must alleviate the attitudes that teaching grammar is "sinful", useless, that it is against the doctrines of modern language teaching methodologies, and that grammar teaching is simply wrong and must be avoided. In daily collegial interaction with even the strongest proponents of the functional communicative approaches to language education, the writer sees the appropriate and proper attitudes towards the teaching of grammar, and pronunciation, in the language class. Language educators have a great faith in the validity of the functional, communicative methodologies in language education, but the proper ones. Now, day after day, a big question can be asked as to where grammar teaching has gone.

The communicative language teaching methodology has shown a great result in making the students able to speak the language with a marked fluency. But, as the present study shows, students' language use has a very low grammatical quality. In this situation, students' language fluency without grammatical accuracy cannot be said as representing students' language proficiency. In communicative events, communication is most effective when there is a balance between fluency and accuracy: the language is spoken in the normal acceptable speed and with correct grammar. Otherwise, as Hammerly (1991: 44) calls it, proficiency without grammatical control is not proficiency but just a communication survival skill.

The re-emphasis of grammar teaching in the syllabus can be done by taking the following considerations:

1. While Hammerly (1991: 78) suggests five stages of form-meaning weightings, I would like to propose a more general balancing between fluency and accuracy by considering the status of English to the learners. It is the point in the continuum of English as a native language and English as a foreign language. Fluency is attached to the native point and accuracy to the foreign point. Using percentages, if fluency counts $50 \%$ and accuracy $50 \%$, the sum will be $100 \%$ standing for language use which is fluent and accurate. A rough visual description will look like this:

\begin{tabular}{|l|c|c|}
\hline & Fluency & Accuracy \\
\hline Native language & $80 \%$ & $20 \%$ \\
\hline Second language & $50 \%$ & $50 \%$ \\
\hline Foreign language & $20 \%$ & $80 \%$ \\
\hline
\end{tabular}

2. The balance for teaching English in Indonesia will be further modified considering other instructional factors such as proficiency levels and localities. For example, classes with low proficiency levels will receive a low percentage of fluency treatment and a higher percentage of accuracy treatment while those with higher proficiency levels will receive a high percentage of fluency and a low percentage of accuracy. In a similar manner, rural schools will receive a low percentage of fluency and a high percentage of accuracy while urban schools will receive a high percentage of fluency and a low percentage of accuracy.

3. In fact, each school or teacher is supposed to have the choice to determine the balance between fluency and accuracy levels each school has its characteristics and the teacher is the one who knows well the students' instructional conditions. This, in fact, is consistent with the national calls in the use of the school-based curriculum.

4. For Indonesian learners, a good instructional material will be that which considers the grammatical structures 
of Indonesian and other regional and local languages across the country as comparative backgrounds. An instructional material like this will be effective and helpful for the learners to see important points in the English grammatical structures. This material, such as one which is often labelled "Common Core English" (Sugeng, Supriyanti, Nurcahyo, 2005), will include such items as:

- $\quad$ finite and non-finite verbs

- verb groups

- verbal and pronominal questions

- passives

- articles

- D-items

- noun phrases

- concords: pronouns, subjects-verbs, determiners-nouns, tenses

- tenses

- clauses

- punctuation: capitalization, periods, question marks

- $\quad$ spelling: apostrophes, consonant doubling, : $i$ before e except after $c$

5. Teachers should not be carried away by certain pressures from the curriculum trends such as, as pointed out by Hammerly (1991: 53), failing to consider the long-term effects of particular curricular innovations. For example, in the text-based syllabus, many teachers spend a large amount of time on the knowledge or theories of text types at the expense of text comprehension and language focus. Knowing the types and characteristics of texts is important; but that is not all. Understanding the texts and knowing the grammar and vocabulary that build the texts are not less important.

A mention must be made on pronunciation and language styles as parts of the information gathered in the study. Pronunciation may be regarded as not a very essential element in communicative events. Besides, English has now become the language of many world's peoples. There has been a tendency to accept different variants of English pronunciation other than the conventionally recognized as standard English such as British and American English. However, it is equally acceptable to expect students to be able to speak English with pronunciation that is close to the standard version of the language. Hammerly (1991: 47), for example, expresses a strong belief that the aim of foreign language education programs should be a standard form of the language. Finally, appropriateness of language use must also become a concern by the language teachers. It is enlightening to hear students speak fluently but it is irritating to hear them use slang expressions in formal conversational events. To re-quote Jespersen (2006:17-8), use of correct English is one that effectively and aesthetically is pleasing to the listener or reader.

\section{Conclusion}

The teaching of English as a foreign language in Indonesia has undergone changes in curricula and results in students' proficiency. There has been a time when teachers and students wrote and spoke English carefully and correctly. This went for around ten years till things became out of control. The study has provided data that, now, students write and speak English with remarkable fluency but with an accuracy level which is truly saddening. This wide-spread phenomenon becomes even more worrying when the students are of teacher education institutions since they will become models for their students when they teach schools.

A change is urgently needed in the syllabus to provide a more balanced treatment of fluency and accuracy by giving a larger amount of grammar teaching in the classroom. A share estimate of 50-50 between fluency and accuracy gives the students possibility to be able to speak or write English fluently with good grammar. Language focus can be oriented at grammatical items that are specific for Indonesian learners such as finite verbs and concords. Similarly, pronunciation and appropriateness must be a part of the language focus of the program syllabus.

\section{References}

Brown, H. D. (2000). Principles of Language Learning and Teaching. (4th Ed.). New York: Addison, Wesley, Longman, Inc.

Brumfit, C. (1981). "Teaching the General Student" in Johnson, K. and Morrow, K. (Eds.). Communication in the Classroom. Hong Kong: Longman Group Limited.

Campoy-Cubillo, M. C., Belles-Fortuno, B. and Gea-Valor, M. L. (Eds.). (2010). Corpus-Based Approaches to English Language Teaching. London: Continuum International Publishing Group. 
Hammerly, H. (1991). Fluency and Accuracy: Toward Balance in Language Teaching and Learning. Canada: Multilingual Matters. Jackson, H. (2005). Good Grammar for Students. London: Sage Publications.

Jespersen, O. (2006). Essentials of English Grammar. London: Routledge, the Taylor \& Francis Group.

Langacker, R. W. (2008). Cognitive Grammar: A Basic Introduction. New York: Oxford University Press, Inc.

Purpura, J. E. (2004). Assessing Grammar. Cambridge: Cambridge University Press.

Richards, J. C. (2006). Communicative Language Teaching Today. Cambridge: Cambridge University Press.

Sugeng, B., Supriyanti, N., Nurcahyo, R. (2005). 'Peningkatan Penguasaan Tatabahasa Bahasa Inggris Mahasiswa Jurusan Bahasa Inggris FBS UNY melalui Pendekatan 'Common Core' yang telah Dimodifikasi'. (Research Report). Yogyakarta: FBS UNY.

Swan, M. (2006). 'Teaching Grammar - Does Grammar Teaching Work?'. Modern English Teacher 15/2.

Thornbury, S. (2002). How to Teach Grammar (5th Ed.). Essex: Pearson Education.

Trousdale, G. and Gisborne, N. (Eds.). (2008). Constructional Approaches to English Grammar. New York: Mouton, the Hague.

Young, D. J. (1984). Introducing English Grammar. London: Hutchinson Education, Ltd.

Zhang, J. (2009). 'Necessity of Grammar Teaching'. International Education Studies 2/2: 184-187. 
